\title{
An investigation on the relationship between TQM and ICT in revenue agency organizations
}

\author{
Mahmoud Bani*, Somayeh abdollahzadeh and Abolfazl Bani
}

Department of Accounting, Damghan Branch, Islamic Azad University, Damghan, Iran

\begin{tabular}{|c|c|}
\hline CHRON I C LE & ABSTRACT \\
\hline $\begin{array}{l}\text { Article history: } \\
\text { Received July 28, } 2013 \\
\text { Accepted 14 January } 2014 \\
\text { Available online } \\
\text { April } 282014 \\
\text { Keywords: } \\
\text { TQM } \\
\text { ICT } \\
\text { Revenue agency } \\
\text { Empowering organization }\end{array}$ & $\begin{array}{l}\text { This paper presents an empirical investigation to study the effects of information and } \\
\text { communication technology (ICT) on total quality management (TQM). The study is applied for } \\
\text { a case study of revenue agency in city of Damghan, Iran. The proposed study consists of } 33 \\
\text { questions in five categories including leadership and commitment of top management team, } \\
\text { customer satisfaction, empowering employees and their partnership, organizational design } \\
\text { perspective and quality of information system. Cronbach alpha has been calculated as } 0.95 \text {, } \\
\text { which validates the overall questionnaire. Using Pearson correlation ratio as well as t-student } \\
\text { test, the study has determined that there was a positive and meaningful relationship between } \\
\text { ICT and TQM components. }\end{array}$ \\
\hline
\end{tabular}

C) 2014 Growing Science Ltd. All rights reserved.

\section{Introduction}

During the past few years, there have been tremendous changes on management systems. In fact, most middle and top-level managers try to use total quality management to improve the performance of their organizations (Twaissi, 2008; Twaissi et al., 2008; Bygstad \& Lanestedt, 2009). According to Schiefer (1999), the concept of quality management marks a major shift process improvement, and customer links to improve customer defined quality of products and services and of process efficiency. In such circumstances, information and technology communication (ICT) contributes on development of management systems. For years, researchers have accomplished various studies to learn about the effects of different factors on improvement of TQM systems. Loukis and Pazalos (2009), for instance, compared the moderating impact of the two basic business process change paradigms including business process reengineering (BPR) and TQM), on the business value generated for organizational by their ICT. They reported that both BPR and TQM had considerable positive moderating impacts of a similar magnitude on the relationship between ICT investment and firm value added. In addition, different BPR and TQM activities had various moderating impacts on

\footnotetext{
*Corresponding author.

E-mail addresses: Bani984m@gmail.com (M. Bani) 
ICT business value; process simplification, process improvement and the creation of a horizontal interdepartmental process were the BPR activities with the largest moderating effects. Liu and Liu (2003) performed similar investigation by investigating the role of new information and communication technologies in the internationalization of firms. They reported that the adoption of new ICTs could the proposed case study to integrate its functional units located in dozens of places across the world. Falk (2005) reported there was a significantly positive relationship between labor productivity growth and the percentage of enterprises with new or significantly changed organizational structures based on industry data for some European countries when ICT components were applied to European firms. Ahmed and Sharma (2008) discussed different concerns associated with the TQM adaptation in virtual organizations. Iles and Healy (2004) investigated on development, implementation and enforcement of codes of conduct designed to govern employees' implementation of ICT in England.

\section{The proposed study}

This paper presents an empirical investigation to study the effects of information and communication technology (ICT) on total quality management (TQM) on revenue agency in city of Damghan, Iran. The proposed study consists of 33 questions in five categories including leadership and commitment of top management team, customer satisfaction, empowering employees and their partnership, organizational design perspective and quality of information system. Table 1 demonstrates Cronbach alpha as well as the number of questions associated with each category of the survey.

\section{Table 1}

The summary of the number of questions and Cronbach alpha

\begin{tabular}{lcc}
\hline Question & \# of questions & Cronbach alpha \\
\hline Leadership and commitment of top management team (L) & 7 & 0.78 \\
Customer satisfaction (C) & 8 & 0.86 \\
Empowering employees and their partnership (E) & 7 & 0.83 \\
Organizational design perspective (O) & 5 & 0.82 \\
Quality of information system (Q) & 6 & 0.88 \\
\hline Total & & 0.95 \\
\hline
\end{tabular}

As we can observe from the results of Table 1, all component of the survey maintain desirable Cronbach alpha, which are well above the minimum acceptable level of 0.70 . Therefore, we can confirm the overall questionnaire of the survey. Table 2 shows details of some basic statistics associated with the component of the survey.

\section{Table 2}

The summary of some basic statistics

\begin{tabular}{lcc}
\hline Question & Mean & Standard deviation \\
\hline Leadership and commitment of top management team & 24.54 & 3.86 \\
Customer satisfaction & 27.64 & 4.84 \\
Empowering employees and their partnership & 24.40 & 4.19 \\
Organizational design perspective & 16.64 & 3.43 \\
Quality of information system & 21.84 & 4.30 \\
\hline Total & 115 & 17.37 \\
\hline
\end{tabular}

Based on the results of Table 2, customer satisfaction maintains the highest mean followed by leadership and commitment of top management team and empowering employees and their partnership. We have performed Kolmogorov-Simrnove test on the data and the results have 
confirmed that all data are normally distributed. Therefore, we may use Pearson correlation as well as t-student tests to verify the relationship between ICT and TQM.

\section{The results}

In this section, we present details of our findings on investigation of the effects of ICT on TQM in revenue agency of city of Damghan, Iran. Table 3 shows details of Pearson correlation test.

Table 3

The summary of Pearson correlation test

\begin{tabular}{cccccc}
\hline \multicolumn{1}{c}{$\mathrm{L}$} & $\mathrm{C}$ & $\mathrm{E}$ & $\mathrm{O}$ & $\mathrm{Q}$ \\
\hline $\mathrm{L}$ & 1 & & & \\
$\mathrm{C}$ & $0.355^{*}$ & 1 & & \\
$\mathrm{E}$ & $0.697^{* *}$ & $0.644^{* *}$ & 1 & & \\
$\mathrm{O}$ & $0.773^{* *}$ & $0.506^{* *}$ & $0.758^{* *}$ & 1 & \\
$\mathrm{Q}$ & $0.521^{* *}$ & $0.587^{* *}$ & $0.799^{* *}$ & $0.818^{* *}$ & \\
\hline L:Leadership and commitment of top management team & & & \\
C:Customer satisfaction \\
E:Empowering employees and their partnership \\
O:Organizational design perspective \\
Q:Quality of information system \\
** Sig. $<0.01$ \\
* Sig. $<0.05$
\end{tabular}

As we can observe, there is a strong and positive relationship between different TQM components. The highest correlation is between quality of information system and organizational design perspective $(r=0.818$, Sig. $=0.01)$. There is also a strong and positive relationship between quality of information system and empowering employees and their partnership $(\mathrm{r}=0.799$, Sig. $=0.01)$. The other positive relationship is between empowering employees and their partnership and organizational design perspective $(r=0.758, r=0.01)$.

We have also performed t-student test to examine the effects of various components of TQM on ICT. Table 4 shows details of our results.

\section{Table 4}

The summary of t-student test between TQM and ICT

\begin{tabular}{lccc}
\hline TQM component & t-value & df & Sig. \\
\hline Leadership and commitment of top management team & 5.269 & 32 & 0.000 \\
Customer satisfaction & 7.877 & 32 & 0.000 \\
Empowering employees and their partnership & 4.645 & 32 & 0.000 \\
Organizational design perspective & -7.316 & 32 & 0.000 \\
Quality of information system & 1.135 & 32 & 0.123 \\
\hline
\end{tabular}

The results of Table 4 clearly show that except one case, quality of information system, all four components influence positively on ICT $(\alpha=0.01)$. Therefore, the effect of TQM on ICT has been confirmed.

\section{Conclusion}

In this paper, we have presented an empirical survey to study the effects of TQM on ICT in one of revenue agencies in city of Damghan, Iran. The study has confirmed that leadership and commitment of top management plays essential role on the success of TQM system. In addition, customer satisfaction is other important factor on TQM adaptation. The study has also determined some positive and strong relationship between different components of TQM. The highest correlation was between quality of information system and organizational design perspective, between quality of 
information system and empowering employees and their partnership and between empowering employees and their partnership and organizational design perspective.

\section{Acknowledgement}

The authors would like to thank the anonymous referees for constructive comments on earlier version of this paper.

\section{References}

Ahmed, N. U., \& Sharma, S. K. (2008). TQM in a virtual organisation: issues and strategies. International Journal of Management and Enterprise Development, 5(5), 541-553.

Bygstad, B., \& Lanestedt, G. (2009). ICT based service innovation-A challenge for project management. International Journal of Project Management, 27(3), 234-242.

Falk, M. (2005). ICT-linked firm reorganisation and productivity gains. Technovation, 25(11), 12291250 .

Iles, J., \& Healy, M. (2004). Quality management and e-commerce: the role of codes of conduct governing the use of technology. The TQM Magazine, 16(5), 354-358.

Liu, S., \& Liu, W. (2003). The role of new information and communication technologies in the internationalization of firms: a case study of Haier. Journal of the Korean Geographical Society, 38(3), 400-412.

Loukis, E., \& Pazalos, K. (2009). An empirical investigation of the moderating effects of BPR and TQM on ICT business value. Journal of Enterprise Information Management, 22(5), 564-586.

Schiefer, G. (1999). ICT and quality management. Computers and electronics in agriculture, 22(2), 85-95.

Twaissi, N. M. (2008). An evaluation of the implementation of Total Quality Management (TQM) within the Information and Communications Technology (ICT) sector in Jordan (Doctoral dissertation, University of Huddersfield).

Twaissi, N., Rollins, R., \& Worsdale, G. (2008, April). A review of current issues and challenges for TQM implementations in the Jordanian information and communications technology sector. In Creating Architecture of Quality and Excellence in the Middle East: Responsibilities, Challenges and Strategies, Quality Congress Middle East (Vol. 2, pp. 7-9). 